\title{
Blinded Like a State: The Revolt against Civil Registration in Nineteenth-Century Brazil
}

\author{
MARA LOVEMAN \\ University of Wisconsin, Madison \\ IN T R O D U C TION
}

The first reports of popular disturbances in connection with Decree 798, calling for obligatory civil registration of births and deaths in the Brazilian empire, surfaced in the early days of January 1852. In the ensuing weeks, men, women, and children from across the impoverished northeastern Brazilian backlands convened in small settlements and towns to protest the decree. Local authorities reported being forced to abandon their posts, fleeing from the "mass of ignorants," who, armed with knives and stones, threatened violence against those who would implement the law. Disturbances were reported in at least thirty-one localities, with crowds estimated at one hundred to several thousand people. ${ }^{1}$

The uprising was largest and most intense in a handful of settlements in the sugar-producing region of Pernambuco. The threat to public order, which

Acknowledgments: Thanks to Peter Beattie, Dain Borges, Rogers Brubaker, Samuel Clark, Jon Fox, Chad Alan Goldberg, Marc Hertzman, Ivan Jaksic, Brian Loveman, Michael Mann, Oriol Mirosa, Gay Seidman, Peter Stamatov, and the CSSH reviewers and editors for useful comments and suggestions. Earlier versions of this paper were presented at the Center for Comparative Social Analysis at UCLA; the Politics, Culture and Society Research Seminar at University of Wisconsin, Madison, and the Historical and Comparative Workshop at Northwestern University. Comments from participants in each of these venues are very much appreciated. Archival research was supported by an IDRF Fellowship from the Social Science Research Council. Additional research support was provided by the University of Wisconsin, Madison Graduate School. Writing was supported in part by a Mellon Postdoctoral Fellowship at the UCLA Center for Modern and Contemporary Studies. All translations are my own unless otherwise noted.

1 Monteiro (1980: 24; 1981) found evidence of uprisings across the northeastern provinces of Pernambuco, Paraíba, Alagoas, Ceará, and Sergipe. I surveyed the correspondence and annual reports of Provincial Presidents for the years 1851-1853 and found reports of popular resistance to Decree 798 in Piauí, Maranhão, and Minas Gerais, in addition to the provinces cited by Monteiro. On closer scrutiny it became clear that the unrest in Minas Gerais, which is the only one of these provinces outside the northeastern region, was provoked by a wave of impressment into the army which coincided with passage of Decree 798, but was not directly linked to it. The army's recruitment drives targeted mining towns in the province because of large numbers of men "without permanent residence" lured there by dreams of striking it rich in the diamond mines (Brazil 1852a: 5-6). 
centered in the hardscrabble farming town of Pau d'Alho, led to the deployment of the 9th Infantry Battalion of the army to pacify the population. Skirmishes between armed regiments and rebels resulted in the deaths of at least two soldiers and the wounding of several others. Retaliation by the army was stayed thanks to the intervention of a Capuchin missionary who persuaded first the commander of the army unit and then the povo ("people") to lay aside their arms. Still, uprisings in neighboring settlements continued and the popular turmoil threatened to spread, prompting the provincial president of Pernambuco to dispatch the 4th Artillery Battalion and call up nearly a thousand national guardsmen to help restore order to the province (Monteiro 1980: 127).

Decree 798 was officially suspended on 29 January 1852 (Brazil 1852b, Decree 907), and the uprisings sputtered out soon thereafter. Though this was presented as a temporary measure, civil registration was effectively cancelled, as was the first general census of the Brazilian Empire that had been scheduled for July of that year. In his address to the General Legislative Assembly in 1852, the Minister of Empire explained: "the Government has not yet been able to proceed with the revision of the Regulations for the General Census of the Empire and for the Register of births and deaths. The grave occurrences that transpired in the execution of those Acts certainly justify in themselves the delay there has been in substituting or altering them." Standing in the way of these efforts, he continued, were "old prejudices and inveterate habits" which, the government had discovered, "it is not easy, or prudent, to openly attack."2

At first glance, the "war of the wasps," as the revolt against the civil registration decree came to be called, ${ }^{3}$ shares much with other eighteenth- and nineteenth-century popular revolts against the encroachments of modernizing states. The transition from indirect to direct forms of rule entailed increasing intrusions by the state into the material and spiritual lives of ordinary people, and these intrusions often met with resistance. The extractive demands of modernizing states, in particular, were perennial triggers of popular protest, as evidenced by the many known revolts against conscription and taxation. ${ }^{4}$ Revolts were also spurred by administrative innovations such as land surveys,

\footnotetext{
2 The Minister also bemoaned other obstacles to the modernization of Brazil's statistical infrastructure, including the "vast extension" of Brazil's territory and the fact that the agency responsible for civil registration and the census was charged with so many other tasks of "immediate and transcendent interest" (Brazil 1853: 33).

3 The name "war of the wasps" (guerra dos mari[m]bondos) appears to have been coined by the author of a 1920 account, who noted that "maribondos" was the nickname given to the "sediciosos" (rebels) (Melo 1920). The uprisings in Paraíba and Alagoas are generally known today as the "Ronco da Abelha" (literally, "the snore of the bee," but figuratively closer to the "roar of the bee"). The stinging-insect metaphor is apt; as a sandal maker in Recife's Mercado São João explained to me in October 2000, "Wasps are those insects that build a nest and don't bother you as long as you leave their nest alone. But if you mess with it ...."

4 See, for example, Burg (2003); Levi (1997); Tilly (1990); Forrest (1989); Beattie (2001: ch. 4).
} 
population censuses, and efforts to standardize weights and measures, usually because such initiatives were seen as means towards states' extractive ends. ${ }^{5}$ In some contexts, new administrative practices also met with resistance because they were seen to contradict religious beliefs, upset established norms of morality, or destabilize fundamental "givens" in peoples' lives. ${ }^{6}$ In the war of the wasps, as in many other cases of popular resistance to the incursions of modernizing states, the stakes were seen to be both material and spiritual. Prompted by fear and fueled by outrage, the northeastern rural poor in midnineteenth-century Brazil were akin to others before and after them, in Brazil and elsewhere, who rose up to defend their livelihoods from the perceived menace of state intrusions.

Yet the popular revolt against civil registration in nineteenth-century Brazil stands apart from kindred episodes, for two primary reasons. First, unlike the vast majority of documented popular uprisings against the extractive, regulative, rationalizing encroachments of modernizing states, the protagonists of the war of the wasps emerged victorious from their confrontation with state authorities. The war of the wasps may have paled in comparison to some of the other tumultuous uprisings that rocked Brazil in the decades following independence from Portugal in 1822 (Palacios 1989: 14). But in contrast to other upheavals, the war of the wasps managed to halt the state in its tracks - at least in this administrative domain. The Brazilian state's effort to lay the foundations for a modern, centralized, statistics-gathering infrastructure was abandoned-if, in retrospect, only temporarily-in response to this revolt. It would be two full decades before the Brazilian state attempted another general census of Brazil (in 1872), and obligatory civil registration would not be implemented with any measure of success until Brazil became a republic, in $1889 .^{7}$

\footnotetext{
${ }^{5}$ Censuses, especially, were often targets of popular ire for their perceived connection to conscription or taxation. See, for example, Cronin (2003), Ploux (1999), Redding (2000), Yin (1999), Pearce (2001), and Bianco (2001: 65). (Thanks to Jing Li for assistance translating Yin's text). On the "quebra-quilo" revolt against standard weights in Brazil, see Barman (1977), Joffily (1976), and Secreto (2003).

6 See, for example, Chace (1989) on a revolt in Dominica in 1844 by freedpersons who feared a census would lead to their re-enslavement; Cohen (2005: 30-33) on religiously motivated resistance to census-taking in Colonial America; Posel (1995) on resistance to civil registration of marriages by South African indigenous chiefs to protect customary practices of polygyny; Goldthorpe (1952) on evasion of civil registration and censuses in East Africa due to the belief it is impious to count people or speak the name of a dead person; Diamant (2001) on avoidance of civil marriage registration in Maoist China for fear that arranged marriages would be made illegitimate; Singha (2003) on denouncement of civil registers in mid-nineteenth-century India by Muslim and Hindu men in the name of protecting women's privacy; and Marinov (1892: 184) on evasion of birth registers by priests and peasants in northern Bulgaria under Ottoman rule due to the belief that registration courted infant mortality and disease. (Thanks to Peter Stamatov for assistance translating Marinov's text.)

7 The remarkable success of the war of the wasps in delaying the imperial state's efforts to enumerate the Brazilian population is noted by Palacios (1989: 14-15). Civil registration was reintroduced in 1874 (Decree 5.604 of 25 Apr. 1874). This time registration was scheduled to begin two
} 
The war of the wasps is even more distinctive on another account. It appears to be the only known instance of a popular uprising in direct response to the introduction of civil registration. ${ }^{8}$ There are examples of popular protests against broader secularization campaigns, in which the introduction of civil registration was one reform among several (e.g., Blackburn 2004: 131; Boylan 2002: 170). But an extensive bibliographic search did not yield a single published account of another revolt against the introduction of obligatory civil registration per se. ${ }^{9}$

The absence of comparable cases does not mean that in other contexts people embraced the idea of registering their births, marriages, and deaths with agents of the state. Most certainly, they did not. But elsewhere, it seems, opposition to civil registration did not catalyze into violent protest; instead, resistance took the form of simple noncompliance or subtle forms of subterfuge. Of course, the same is true of resistance to other potentially intrusive administrative innovations of modernizing states, such as censuses, land surveys, and standardized weights and measures. It is well known that the array of "everyday forms of resistance" (Scott 1990) are more likely responses to a grievance than is collective protest or revolt. Opposition to the state's quotidian administrative practices was (and is) especially likely to take the form of evasion rather than direct confrontation. But it is also true that certain kinds of objectionable practices are more likely to produce a collective response than others. The very nature of civil registration as a state practice that is temporally diffuse, individualized, and administratively decentralized no doubt makes it a less probable

years after the general census, instead of six months before it, and the registers were put in the charge of parish priests. The memory of the 1852 disturbances was explicitly invoked when the Chamber of Deputies discussed the matter on 8 April 1870 (Brazil. Congresso. Câmara dos Deputados 1977: 594). The 1874 law did not provoke opposition, but it did not establish civil registration either, as evidenced by the introduction of civil registration again thirteen years later (Law 3.316 of 11 June 1887), and yet again more than once after that (Decree 9.886 of 7 Mar. 1888) (Meira 1994). As late as the 1940s, a proposal to the President of the Republic to reform civil registration lamented the pitiful state of vital statistics in Brazil (Conselho Nacional de Estatística 1951, anexo XXVI).

8 The war of the wasps is often glossed in the historiography as a revolt against the 1852 census. This is understandable, in the absence of a detailed account of this episode, given that Decree 798, which called for obligatory civil registration of births and deaths, was enacted simultaneously with Decree 797, which established the procedures and set the date for Brazil's first general census. The timing of the uprising, however - it began the day Decree 798 was to become law - suggests it was primarily in response to civil registration, rather than the census that loomed several months in the future. This is confirmed by the primary sources.

9 Granted, there may be known cases of popular protest against the introduction of obligatory civil registration that did not surface through conventional search strategies, especially due to language or place of publication. The lacuna of incidents comparable to the war of the wasps could also be an artifact of the relative neglect of historical research on civil registration independent of other nineteenth-century secularization reforms. As Diamant notes, "studies of how registrars acted or how ordinary people dealt with central state authorities in this regard are quite rare. Even Scott, who focuses on processes of creating legible populations through various means, tells us very little about the state institutions that were actually assigned to implement these lofty goals" (2001: 449). 
target for collective response than a census, which is a pre-scheduled and discrete event that is experienced-ideally at least-by large numbers of people in a given locale nearly simultaneously. Perhaps for this reason, censuses often became targets of popular protests against the state, while uprisings in opposition to civil registration appear to have been exceptionally rare.

The war of the wasps thus appears as an historical anomaly that calls out for explanation. If, amongst the range of ways that modernizing states intruded into the lives of ordinary people, the introduction of civil registration was particularly unlikely to incite collective unrest, what provoked the violent popular protest against civil registration in mid-nineteenth-century Brazil? This article draws on a combination of archival materials, published primary sources, and secondary scholarship to offer an answer to this question. ${ }^{10}$ Historical analysis of this remarkable episode deepens our understanding of how state-society dynamics in nineteenth-century Brazil profoundly influenced the pace and trajectory of Brazilian state formation. More broadly, the analysis generates new insights into the history of efforts by modernizing political elites to establish the administrative-technical means of "seeing like a state" (Scott 1998).

Scott emphasizes the centrality of "projects of legibility" and simplification to the construction of modern states, and to their ability to intervene effectively in society (for better or for worse). The advent of standardized metrics for describing land and people made it possible for states to "see"- and thus administer, regulate, extract, and intervene - in ways they could not before. In Scott's words: "The pre-modern state was, in many crucial respects, partially blind; it knew precious little about its subjects, their wealth, their landholdings and yields, their location, their very identity. It lacked anything like a detailed 'map' of its terrain and its people. It lacked, for the most part, a measure, a metric, that would allow it to 'translate' what it knew into a common standard necessary for a synoptic view. As a result, its interventions were often crude and self-defeating" (1998: 2).

On this account, basic administrative foundations such as standardized naming practices (e.g., permanent patronyms), censuses, universal weights and measures, cadastral surveys, and maps, were crucial prerequisites to effective state intervention in society. Such "tools of legibility" delivered pre-modern states from their blindness with respect to the natural and human resources they aspired to control.

${ }^{10}$ Brief mention of the war of the wasps can be found in Barman (1988: 236), Eisenberg (1974: 196), Carvalho (1996: 13), McCreery (2002) and Souza e Silva (1986[1922]). More vivid descriptions are provided by Melo (1918; 1920), Joffily (1976: 77-83, on uprisings in Paraíba), and Secreto (2003, on Ceará). Historical analyses include Monteiro (1981) and Palacios (1989), discussed below. After the present article was in press, a forum centering on Palacios' little-known account of the Guerra dos Marimbondos appeared in the on-line journal almanack braziliense n.03 (May 2006). (http://www.almanack.usp.br/PDFS/3/03_apresentacao_pt.pdf). Unfortunately, I was unable to incorporate the insightful contributions to this forum, by Hebe Maria Mattos and Maria Luiza Ferreira de Oliveira, into the analysis in this article. 
Looking back from today, it seems clear that the lack of a "synoptic view" did hamper pre-modern states' efforts to intervene in society. Yet episodes such as the war of the wasps suggest that the lack of basic schemes of legibility and standardization was not the primary impairment to modernizing states' visual acuity. Indeed, as the analysis below reveals, the faltering of legibility projects in nineteenth-century Brazil was itself symptomatic of a more profound blindness.

To anticipate, the Brazilian state failed to preempt the war of the wasps because it was blinded by an illusion of state legitimacy and power that far surpassed actual state capacity. Brazil's political elite mistook the trappings of modernity in the imperial capital for the modern, territorial nation-state which they imagined - a state which had not yet been fully created, let alone consolidated. ${ }^{11}$ They mistook their own taken-for-granted commitment to "progress" for popular willingness to embrace change. And once the uprising began, they mistook violent opposition to Decree 798 for evidence of the backwardness, irrationality, ignorance and stupidity of the poor, rural population.

Together with the Western European proponents of "enlightened" government whom they emulated, Brazil's nineteenth-century state builders were ideological predecessors of the twentieth-century "high modernists" described by Scott (1998: 89-90). They had faith in science, in rationality, and in the inevitable triumph of "modernity." They saw themselves as apostles of progress. ${ }^{12}$ And their ideological conviction in the promise of modernity entailed, as a corollary, the systematic disdain for "traditional" knowledge and modes of life. The "hinterland" and its people and customs were construed as objects of their modernizing gaze, not subjects who might have something to contribute to their own "modernization."

The ideological drive to impose progress on the people was itself a major source of blindness for the modernizing Brazilian state. Ironically, it severely

11 Some political elites were more inclined to such illusions than others. In August of 1870, the Minister of Empire submitted a request to the Chamber of Deputies for unlimited funds to conduct a general census of Brazil on 31 December 1870. Deputy José de Alencar opposed the proposal, and chastised the Minister for his delusional faith in the administrative prowess of the Brazilian state. With such a short lead-time, he argued, “. . . it would be physically impossible to take this census, not just in ... remote Provinces that are more than thirty days distant from the Capital of the Empire, but also in the Provinces closest to the Capital." Decrying the census of the Corte (Rio de Janeiro) earlier that year as a laughable failure, de Alencar predicted that the Minister of Empire's "pompous" project would be completely in vain. Worse, "far from producing the grand benefit that should be expected from his efforts ... the census would be a great evil [for] there is nothing worse than false statistics.... All the writers who work on this subject say that an inexact statistics are much more prejudicial than no statistics at all" (Brazil. Congresso. Câmara dos Deputados 1977: 591-611).

12 In his report to the Minister of Empire in 1875, the interim director of the Brazilian Directorate of Statistics (DGE) wrote that the "glorious mission" of the population census is ". . .so noble that the census agents should be considered apostles of civilization, of justice and of the happiness of peoples" (Brazil. Directoria Geral de Estatística 1875, "Recenseamento da População do Imperio," 1-2). 
and systematically limited the state's capacity to "see" precisely those "objects" (rural people and their modes of life) that state-builders believed stood between Brazil and Modernity. Zealous adherence to modernist ideology rendered the quotidian exploitation and impoverishment of Brazil's rural population all but invisible (or irrelevant) to the eyes of state-builders. The condition of the populace was of concern in the abstract; the "improvement of the population" was frequently the stated end of state policies. But the population's diverse needs, wants, concerns, and fears did not generally figure in the design or execution of state-building initiatives in the first place.

Like Scott's twentieth-century "high modernists," nineteenth-century apostles of progress were not ideologically disposed to tapping local sources of knowledge or legitimate authority in pursuit of their own ends. As a result of their systematic disregard for local knowledge and ways of life, a tremendous cognitive and experiential gulf divided modernizing elites from those they sought to modernize. In the context of consolidated modern states, as Scott's (1998) work makes clear, the failure to bridge this gulf could result in an "overdose" of the state, with tragic human consequences. Where states are still in their adolescence, in contrast, the present article shows that this same failure can breed misunderstandings that obstruct the development of modern state infrastructure from the start. ${ }^{13}$

The irony in the case of the war of the wasps, of course, is that the state's failure to take local conditions into account directly undermined a measure that aimed precisely at making the population more "visible" to agents of the state. The lack of a "synoptic view" of society no doubt hindered the development of the Brazilian state prior to the late nineteenth century. But the war of the wasps suggests that the state's self-imposed blindness to local conditions was a much more serious handicap.

THE WAR OF THE WASPS

\section{Political Setting}

The war of the wasps took government officials entirely by surprise. They could not fathom why the populace would take up arms to combat such a harmless and progressive measure. The imperial government had anticipated some

${ }^{13}$ In a previous article I developed an analytic framework for considering how new domains of administrative activity come to be seen as legitimate state practices (Loveman 2005). The success of efforts to extend the state's administrative reach and consolidate the state's legitimate authority hinge, at least in part, on whether state-builders decide to innovate, imitate, usurp, or co-opt traditional practices and relations of authority. The framework put forth in that article, which includes a summary account of the war of the wasps, draws attention to the relationship between central state actors and local or customary authorities as a potentially pivotal influence in the development of state capacity, and thus in the pace and trajectory of modern state formation. The present article can be read as a companion to that piece; it provides historical analysis of the revolt against civil registration, including consideration of its broader socio-historical implications. 
logistical difficulties in the implementation of the decree, including some degree of noncompliance or fraud, and the possibility of resistance from parish priests. After all, even France had encountered such obstacles in its effort to establish civil registers over fifty years earlier (Noiriel 2001). But a violent popular revolt was another matter altogether.

The surprised response of government officials is itself somewhat surprising, given the turbulence and social strife across the Brazilian empire in the decades leading up to the revolt. Brazil's negotiated independence from Portugal in 1822 ushered in factional disputes over the limits of monarchical authority in the nascent constitutional monarchy. Political stalemate culminated in Pedro I's abdication of the throne in 1831, in favor of his five-year-old son, Pedro II. Regents were appointed to govern until Pedro II reached maturity, and they took the opportunity to indulge liberal visions and devolve considerable political autonomy to the provinces.

The Regency lacked legitimacy in the eyes of many Brazilians, however, and the decentralizing reforms had the opposite of their intended effect. In the 1830s, regional nativisms fueled major revolts across Brazil. ${ }^{14}$ As the Regency struggled to reassert the primacy of the center over the provinces (the 1837 Regresso), liberals protested lost prerogatives. Intense opposition cascaded into major rebellions that often spilled over into the "dangerous classes" and, in some cases, threatened the territorial integrity of the empire. Lacking sufficient coercive capacity to restore order on it own, the imperial government relied on the mobilization of local allies to suppress these rebellions. The side of the imperial government ultimately prevailed.

Having eliminated secessionist threats, the imperial state-now with Emperor Dom Pedro II at the helm - set out to extend its authority over the expanse of Brazilian territory. At mid-nineteenth century, the Brazilian state exercised only fragile administrative and normative control over the country's vast territory and widely dispersed population. The imperial government sought to rectify this situation through a bombardment of political reforms and administrative initiatives. A political party system introduced in 1844 had helped to reconfigure and tighten the linkages between national, provincial, and local politics. ${ }^{15}$ In the 1850 s, the imperial government introduced measures to reform the national treasury in Rio, regulate national commerce, reorganize the judiciary, create a private Bank of Brazil, regulate access to land (in part through a new agency to survey and register existing land titles), construct a

\footnotetext{
14 Among the most notable rebellions of the 1830s are the Cabanagem in Pará (Cleary 1998), the Farroupilha in Rio Grande do Sul (Barman 1988; Flores 1978; Bento 1986), and the Male rebellion in Bahia (Reis 1993), all in 1835, the 1837 Sabinada in Bahia, where rebels proclaimed Bahia a "free and independent State" (Barman 1988: 195; Kraay 1992); and the 1839 Balaiada in Maranhão (Janotti 1987).

${ }^{15}$ On party politics in nineteenth-century Brazil, see Graham (1990), Needell (2001), and Bieber (2001).
} 
national railroad, reform the medical and law schools, reign in National Guard units, reform the army, and rationalize sanitation to fight disease (Barman 1988: 234-35). Among these initiatives, the government issued decrees calling for obligatory civil registration and the first general census of the Brazilian Empire.

\section{Civil Registration on Paper: Decree 798 of 18 June 1851}

Imperial decree 798 of 18 June 1851 stipulated that obligatory civil registration of births and deaths would commence 1 January 1852, in preparation for the first general census of the Brazilian Empire, to take place on 15 July 1852 (Brazil 1852b, Decrees 797 and 798). The imperial government had both pragmatic and symbolic reasons for implementing civil registration and taking a general census of the population. Imperial bureaucrats increasingly recognized that the lack of reliable population estimates undermined rational administration and governance. ${ }^{16}$ The political elite also looked abroad and saw other "civilized nations" had civil registers and took censuses of their populations. The production of population statistics played an important legitimating function in an emerging world-polity of nation-states (Meyer 1987; Ventresca 1995; Loveman 2001). This is aptly expressed in one of the first newspaper articles to decry the uprisings against Decree 798: "All the civilized countries proceed in this manner, the government of Brazil could not help but do the same."17

Decree 798 included step-by-step instructions for the registration of births and deaths, specifying who should register whom, in what space of time, and with what repercussions for failure to comply. The registers were placed in charge of the escrivães dos juizes de paz (scriveners of the justices of the peace), who were entitled to collect nominal fees for issuing certificates "corresponding to the fees collected by private notaries." Births were to be registered within seventy-two hours. Priests were instructed not to baptize infants in the absence of a certificate from an escrivão, unless the survival of the newborn was in question. Legitimate children were to be registered by their fathers, illegitimate children by their mothers, slave children by their owners or fazenda administrators, and abandoned children by whomever found them. Deaths, meanwhile, were to be reported to an escrivão within twenty-four hours. This burden fell to the head of the family of the deceased, his successor in the case of his own death, or to the person who witnessed or first learned of the death. ${ }^{18}$ Burial in church cemeteries was made contingent on an official certificate of death (Brazil 1852b, Decree 798).

\footnotetext{
16 See, for example, debates in the Senate on 14 February and 13 August 1850 (Brazil. Senado Federal 1978).

17 Diario de Pernambuco, 5 Jan. 1852: 2. Concern about Brazil's image abroad intensified around 1850 when the Brazilian government succumbed to British pressure to halt the importation of slaves, but continued to defend slavery within its borders (see Barman 1988: 233; Toplin 1972).

18 Provisions were also included to establish responsibility for recording deaths in public establishments such as prisons and hospitals, in the army, in cases of capital punishment, and deaths at
} 
Decree 798 specified precisely what would be recorded in civil registers. Declarations of birth would include the newborn's name, sex, and the hour, day, month, year, and place of birth, along with the parents' names, occupations, and residence. ${ }^{19}$ Special instructions applied to indigenous, abandoned, and slave infants. For children of indigenous parents, the escrivão would make note of the "tribe or nation." For abandoned newborns, the escrivão would note "identifying signs" and circumstantial informational that could help the infant "be known." For infants born of slave mothers, the registration would include the owner's name, date, and place of birth, sex and color of the newborn, and parents' names, or only the mother's name if she were single. The escrivão would also record if the child were granted freedom at birth. Death registers required similar information, along with indication of "cause of death." As in the case of births, Decree 798 required that "color" be recorded in death registers only when the deceased were slaves (Brazil 1852b, Decree 798, Arts.8, 11).

The escrivães were to report aggregate numbers of births and deaths to the government every six months. The model tables provided for this purpose (see Fig. 1) reveal the distinctions amongst the population that most interested the state: legal status (free versus slave, with indigenous occupying an ambiguous position), and legitimacy of birth. ${ }^{20}$

"Color" was notably absent from the forms for reporting aggregate data. By the end of the nineteenth century, the Brazilian state would become very interested in the "color" of its population as a whole, and aggregate racial statistics would be marshaled to make claims about prospects for the nation (Loveman 2001, ch. 5). But on the heels of the 1850 ban of slave imports, the distinction between freepersons and slaves overshadowed distinction by "color" for those concerned with the future of the Brazilian nation. ${ }^{21}$ While it was deemed useful as an identifying characteristic for slaves, "color" was not prioritized in the collection of population statistics by the imperial government in 1852 .

On paper, the projects of implementing obligatory civil registration and, six months later, carrying out the first general census of the Brazilian Empire, appeared meticulously planned and thoroughly rational. By all appearances,

sea. In the latter case the registration was to be done on board the ship, then sent to the Naval Ministry in the Imperial Court or to the relevant provincial president, who would forward it down through the appropriate administrative channels to reach the local escrivão.

19 For illegitimate children, the names of the mother and father "who recognizes" the newborn would be recorded, or only the latter if "the mother does not want to declare hers."

20 On the social significance of "legitimacy" in imperial Brazil, see Lewin (2003).

21 "Color" was also absent from the list of inquiries to be made in the ill-fated 1852 census. In his analysis of the 1835 census of Iguape, Bahia, Barickman (2003) also found that legal status was prioritized over "qualidade" (color/race). Distinctions of "color" and legal condition (condição) did not map neatly onto each other in nineteenth-century Brazil. In the 1835 Iguape census, for example, nearly 47 percent of slave-owners were not "white" (Barickman 1999). 


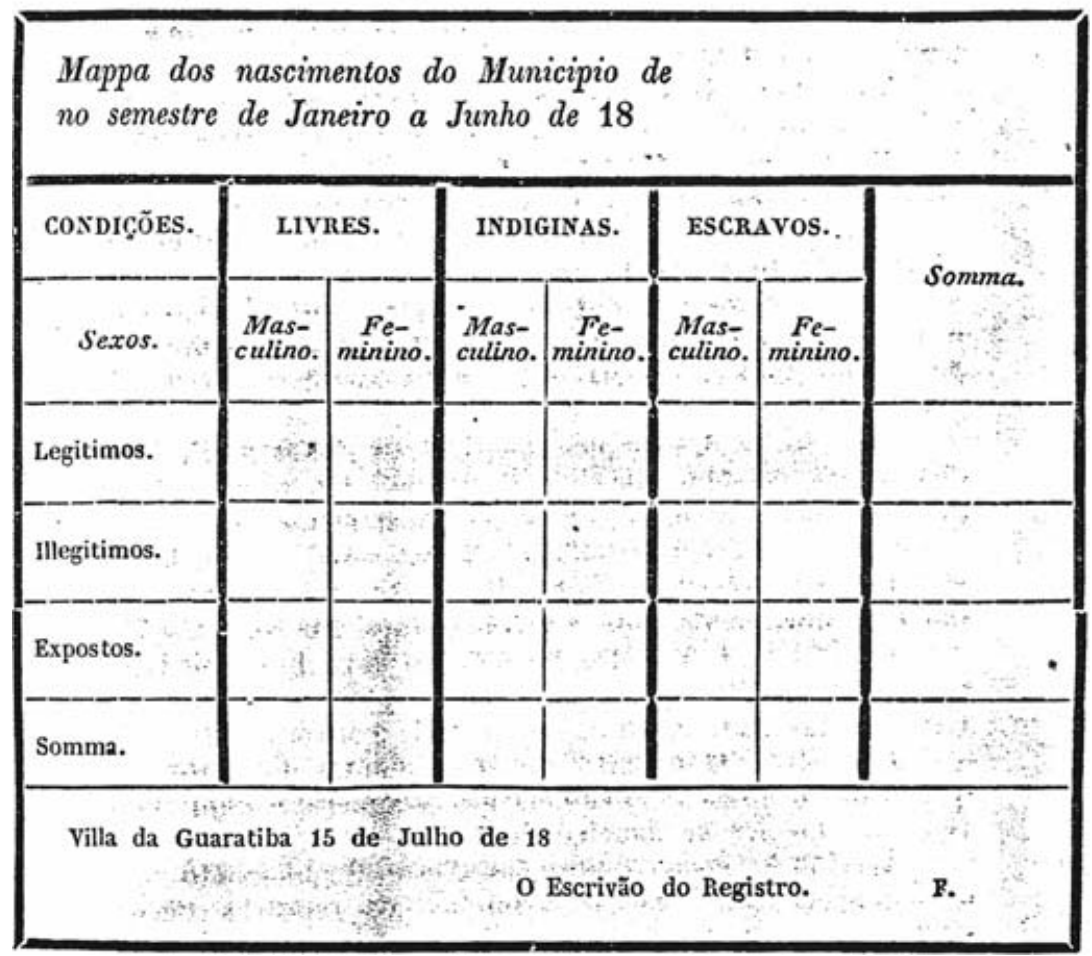

Figure 1 Model Table for Reporting Births by Municipality in Brazil, 1852. "Table of births in the municipality of in the semester from January to June of 18 ." Source: Brazil 1852b, v.14, pt. 2, sec. 32.

Brazil would soon join other "civilized nations" whose collection and use of population statistics made possible (in theory) "enlightened governance." But from the day Decree 798 was supposed to take effect, it quickly became clear that the Brazil imagined by the imperial political elite did not yet exist in reality. A vast gulf divided the official Brazil of the Imperial Court, and the "real" Brazil, where conditions of life had not improved since the beginning of the century - which is to say, they remained miserable. The revolt against the execution of Decree 798 testified to this fact (Barman 1988: 236).

\section{Civil Registration in Practice: From Administrative Failure to Violent Opposition}

Efforts to implement Decree 798 got off to a rocky start. The government had not managed to distribute the official forms to escrivães in time, making compliance 
with the law impossible. Parish priests complained that they should not have to withhold baptism under the circumstances. ${ }^{22}$ The imperial government responded quickly, with an official circular allowing priests to continue performing sacred rites where the proper forms had not arrived. ${ }^{23}$ This glitch revealed the limited administrative reach of the central Brazilian state. If poor means of communication, inadequate funding, and unqualified personnel made it difficult to establish civil registers in France in 1792 (Noiriel 2001), the obstacles were multiplied several-fold for Brazil, though the architects of Decree 798 seemed unaware of this. As it turned out, inadequate administrative capacity was only the first obstacle to the introduction of civil registration in Brazil.

In the first days of January 1852, local papers began to mention seemingly isolated incidents of popular unrest in relation to the implementation of Decree 798. The Provincial President of Pernambuco, meanwhile, began receiving letters from priests who feared their compliance with Decree 798 would have grave repercussions. One priest reported, for example, that the population of Timbaúba was "attacking" the decree, and that "even women, armed with knives and pistols," threatened to assassinate him if he demanded the official certificate to perform baptisms. Another wrote from his parish in Bom Jardim, "the povo, without exception of a single individual, was possessed by a panicky terror" at the rumors circulating about the intent of the decree, and that as a consequence his "life was in considerable danger." ${ }^{24}$ At first the rioters focused especially on those who would read the decree aloud, an act that would make the words on paper into the law of the land. In one instance, for example, it was reported that "more than two hundred people of both sexes (with women the most enraged)" raided the property of the juiz de paz and "almost assassinated" him because they believed he was hiding "the paper" (a physical copy of Decree 798). The judge's sexagenarian mother-in-law dropped to her knees and, "with a crucifix in her hands, assured them in the name of [Jesus Christ] that her son-in-law did not have such a paper." 25 Other authorities felt threatened as well; many abandoned their posts and fled to neighboring towns or the provincial capital.

The provincial government of Pernambuco tried to downplay the disorders. The partisan newspaper, Diario de Pernambuco, reported on 7 January that peace had been restored throughout the province even as troops were dispatched to Pau d'Alho to "pacify" the population. The provincial president also called upon secular and religious authorities to do everything in their

\footnotetext{
22 See, for example, letters from priests to the President of Pernambuco in Arquivo Público Estadual Pernambucano. Documentos Manuscritos. Autoridades Eclesiásticas (hereafter APEP-DM-AE) 1852: 1-3.

23 APEP-DM-AE 1852: doc. 12.

24 APEP-DM-AE 1852: docs. 16, 3.

25 Jornal do Commercio, 16 Jan. 1852: 1, reproducing a letter sent from Recife, Pernambuco,
} dated 7 Jan. 1852. 
power to dispel misunderstandings and reaffirm the "good intentions" of the imperial government.

The 9th Infantry Battalion, a rag-tag unit of ninety-some men commanded by Lt. Colonel Hygino José Coelho, was sent to put down the uprising. The Lt. Colonel wrote diligently to his commanding officer on his way to Pau d'Alho, declaring that he would use all means at his disposal to pacify the populace. Following an ambush that left two of his men dead and five wounded (with no casualties suffered by "the aggressors"), Coelho reported that the use of force would be necessary to reestablish order to the province. ${ }^{26}$

In public statements the provincial president expressed faith in the army's ability to restore order to the interior, but he also hedged his bets, calling upon religious authorities to use "persuasive means" to defuse the uprising. The Capuchin missionary Frei Caetano de Messina arrived in Pau d'Alho before the armed regiment. ${ }^{27}$ He had made considerable headway convincing the people of Pau d'Alho to lay down their arms and return to their homes when rumors of the infantry's approach re-ignited the rebellion. Apparently, although the battalion commander knew the missionary had been sent to defuse the uprising, Frei Caetano was never informed that his kind words would be backed by the threat of brute force. To the rebels it appeared the priest had betrayed them, and Frei Caetano found himself in the awkward position of trying to dissuade the battalion commander from using force so that he might regain his legitimacy in the eyes of the populace and convince them again to lay down their arms.

He ultimately succeeded, persuading the Lt. Colonel to wait a while longer before occupying the town, so that when the soldiers converged on Pau d'Alho it was already "pacified," as signaled by the fact that the "houses were covered with green branches and several people carried white flags." ${ }^{28}$ With the immediate threat of escalation out of the way, Frei Caetano began to channel the energies unleashed by the uprising into sustained religious rituals and processions. Citing "a reliable source" ("uma pessoa fidedigna"), the Diario de Pernambuco reported on 12 January 1852 that when the battalion entered the town, Frei Caetano solemnly handed the Commander a white flag with an image of the sacred Heart of Maria, and said: "'Here is the sword, Sr. Commandante,' who, receiving it, replied, 'I am very glad to receive this sword,' and kissing the image devotedly, he raised the flag." The newspaper article recounted that the missionary then entered the church "and the 'povo' began

\footnotetext{
26 Report from Lt. Colonel Hygino José Coelho to Victor d'Oliveira, president of the province of Pernambuco, sent from the Engenho Cajueiro, 6 Jan. 1852 (Arquivo Público Estadual Pernambucano. Oficiaes do Exército [hereafter APEP-OE] 1852: doc. 2).

27 On nineteenth-century Capuchin Missions in northeastern Brazil, see Barman (1977); for biographical notes on Messina, see Santos (1994: 573-74).

28 Report from Lt. Col Hygino José Coelho to Victor d'Oliveira, president of the province of Pernambuco, dated 10 Jan. 1852, printed in Diario de Pernambuco, 12 Jan. 1852: 2.
} 
to pray, singing, and the national hymn was played, and the missionary raising his voice gave 'vivas' to the divine patron saint of Pau d'Alho (The Divine Espirito Santo), to the Blessed Religion, to the Blessed Majesty the Emperor, to the President of the Province, to the Commander of the column, to the expeditionary troops, and to the religious povo of Pau d'Alho, with all these 'vivas' being enthusiastically responded to by the povo" (Diario de Pernambuco, 12 Jan. 1852: 2).

On Frei Caetano's own account, he stayed in Pau d'Alho twenty-one days, giving mass each night in which he spoke of "the Triumph of Religion," and leading candle-lit processions of the portrait of the Virgin of Bom Conselho. The processions culminated in the burning of various "items of luxury," including weapons of diverse sorts "though not in the numbers" he would have liked. ${ }^{29}$ Frei Caetano also performed an array of missionary work, including performing marriages for numerous couples, making repairs to the church and cemetery, hearing confessions, and giving communion. Frei Caetano wrote to the provincial president to explain, "It was not fear of military force, which only irritated them further, that obliged them to put down their weapons, it was only the reign that Sacred Religion still has over them."30

Though relatively small and short-lived, the armed insurrections in Pau d'Alho and surrounding areas prompted the imperial government to suspend Decrees 797 and 798 on 29 January 1852. In his annual report to the Legislative Assembly in 1852, the Minister of the Empire blamed the "grave occurrences" in the northeast for the government's failure to implement the decrees. Civil registration and the census planned for 1852 were ultimately cancelled. ${ }^{31}$

Together with more widespread forms of passive resistance throughout the Empire, the uprisings in the northeast made it clear that it would take more than a nicely written set of decrees to enable the Brazilian state to systematically record all births and deaths in its territory. While widespread administrative and logistical failures lay bare the stunted administrative reach of Brazil's imperial bureaucracy, the war of the wasps revealed that imperial political elites were all but blind to conditions on the ground for Brazil's majority rural poor population.

WHY A REVOLT?

Decree 798 looked very different to the imperial government than it did to the poor, rural population whose births and deaths were to be registered. The imperial government saw civil registration and the general census as necessary and desirable administrative innovations, measures that signaled Brazil's

29 Letter from Frei Caetano de Messina to Victor d'Oliveira, dated 21 Feb. 1852 (APEP-DM-AE, 1852: doc. 45).

${ }^{30}$ Letter from Frei Caetano de Messina to Victor d'Oliveira, dated 21 Feb. 1852 (APEP-DM-AE 1852: doc. 45).

31 The Decrees were, in fact, revised by the Council of State, but the revised measures were never instituted (Arquivo Nacional, CX515, Pac. 2, doc. 38). 
modernity to the world and lay the administrative foundations to make Brazilian modernization a reality. The northeastern povo, in contrast, experienced the measures as arbitrary and suspect impositions, threatening both their physical livelihood and spiritual well being. Not surprisingly, the reasons for the revolt appear very different when viewed from each of these vantage points.

\section{The View from Above: Conspiracy, Rumor, and Ignorance}

Provincial government authorities in Pernambuco had little doubt that the uprising against Decree 798 was the work of political foes. Memories of the Praieira rebellion of 1848-1849 were still vivid. The rebellion had pitted the local power networks of the Liberal party against those of the Conservatives, completely destabilizing the province fewer than two years earlier. The Liberals were narrowly defeated, and the rebellion left in its wake a context of intense political animosity and suspicion. ${ }^{32}$ Official sources, including the Conservative Diario de Pernambuco, tended to attribute the uprising against Decree 798 to the misdeeds of out-of-power Liberals. In an article dated 4 January 1852 (printed 5 Jan. 1852: 2), for example, the Diario de Pernambuco reported, "We know that ill-intentioned individuals, not wanting to let pass any occasion to create embarrassment for the government, have sought to bias the less sensible population of the interior of the province against the law of registration of births and deaths...."

Liberals were accused of capitalizing on the povo's ignorance by starting a vicious rumor: that the aim of civil registration was to enslave the free poor of color. Decree 798 was dubbed the "law of captivity" (lei do captiveiro). The Conservative provincial government was convinced both that this rumor was to blame for the popular disturbances, and that Liberal partisans were the source of the rumor. The provincial legislative assembly made public this view in its annual report to the provincial president, which stated that the disorders across the northeastern interior in response to Decree 798 were caused by "the fateful and absurd prejudice that overcame the spirit of the rash populace who could be made to believe that the Decree's aim was to enslave men of color" (Brazil 1852c: 3).

The Liberals hastened to defend themselves, denying any role in the chaos. In the words of a prominent leader of the Pernambucan Liberal party, “....I declare in the most solemn and positive manner that I do not have any part in these movements, either directly or indirectly; loud and strongly I condemn them as opposed to civilization and as an infallible way of retarding

32 The Praieira rebellion is generally characterized as a partisan struggle, but party loyalties at the provincial and local levels did not map directly onto national-level party politics. Mosher (2005) argues that the fault lines in the Praieira conflict were strongly shaped by family loyalties and local patronage power networks. On the Praieira rebellion, see also Marson (1980; 1987), and Carvalho (2003). 
the march and progress of the Liberal party. ..."33 Another Liberal party leader proclaimed, ". . . I declare before God and men that I not only disapprove of the antics and craziness of those delusional men who rebelled against the execution of the laws of the country, but that from this moment I offer my services to the government to help it maintain order and public security." 34 Some opposition newspapers also argued emphatically that Liberals and parish priests were targets of violence along with other local authorities, as if this alone proved the absence of complicity with the rebels.

Even as official (Conservative) newspapers decried those willing to rile up the masses to destabilize the government, they sought to retain the appearance of order in news that reached the Imperial Court in Rio. Conservative party leaders attacked enemies of the government for spreading both the rumor about the sinister intentions of Decree 798, and the "rumor" that this had led to mass uprisings throughout the province. According to a report printed on the front page of the Diario de Pernambuco on 7 January 1852, the "rumors" that the interior of the province was up in arms and that "Brazilian blood" had been spilled in several locales were completely groundless; there was only a small uprising in the parish of Pau d'Alho, and public tranquility there had already been restored. Liberal papers, in contrast, did not downplay the revolts, but they did dispute the "rumors" that the povo actually believed that the government intended to enslave free men of color: "our population knows perfectly well that no government would be capable of making slaves of free men." 35

In addition to Praieira Liberals, parish priests were also singled out as possible instigators of unrest among the impressionable masses. Though they mostly escaped direct accusation, the historical record includes many passing references to the possibility that priests were fomenting discontent rather than working to ameliorate it. This is not surprising, especially given public criticism of Decree 798 by the Church hierarchy. Anticipating the "inconveniences" the decree would cause, on 15 December 1851, the Archbishop of Bahia published a letter to Pedro II in a Catholic newspaper asking him to reconsider the wisdom of the regulations, especially the articles that prohibited parish priests from performing baptisms and burials without the requisite certificates.

${ }^{33}$ Letter from Dr. Jeronymo Vilella de Castro Tavares, dated 7 Jan. 1852, published in Diario de Pernambuco, 10 Jan. 1852: 1.

${ }^{34}$ Letter signed by Ignacio Bento de Loyola, 9 Jan. 1852, published in Diario de Pernambuco, 10 Jan. 1852: 1. On provincial newspapers as battlegrounds for personal attacks over political honor, see Bieber (2001).

${ }^{35}$ O Paladim, 5 Feb. 1852: 2 (Biblioteca Nacional, Rio de Janeiro. Seção de Obras Raras [hereafter BNRJ-SOR], P19, 4, 9). The article continues: “. . . and really, which government, daring to pass a decree declaring all the free population to be slaves would not blow up immediately like the shrapnel of a bomb? Further, what government of Brazil, wanting at this time to install absolute law, would not be immediately crushed, and its supporters torn to pieces by the masses?" 
A tone of affront was established in the first sentence of the Archbishop's lengthy letter, as he remarked that he had learned about Decree 798 secondhand, from parish priests who had heard about it from "diverse civil authorities." 36 The Archbishop did not doubt that the decree was executed with "the best intentions." Yet, the Archbishop continued, he would be deserving of scorn if he were to "keep captive the truth of God" and fail to notify the Emperor of the dire inconveniences that would result from execution of the decree in the interior of the country. In the northeastern backlands, he explained, the Church was engaged in a constant fight against the threat of "religious indifference." The tendency for parents to neglect to baptize their children, due largely to conditions of extreme poverty and isolation, was a serious concern. The Capuchin missions begun in the 1840s had made some inroads, "protecting the empire's souls" with yearly visits to remote, sparsely inhabited areas for mass baptisms and marriages. But the new decree threatened to undermine these efforts by placing parish priests in the difficult position of either going against "the impulses of pastoral charity" and denying baptism when the parents had not secured the official certificate, or facing punishment by the state. In essence, the Archbishop wrote, Decree 798 would force parish priests to choose between "submission to the powerful veto of the escrivão of the peace and obedience owed to the orders of Heaven."

The Archbishop called on Pedro II to rethink the decree. Appealing to the Emperor's paternal heartstrings, the Archbishop asked: "Wouldn't the paternal heart of Your Royal Emperor be saddened by the lamentable scene of innocent children, poor little lambs who demand the sacred rite [aprisco] to purify themselves of the original sin, repelled by their own pastor, paying once again the fault or neglect of their parents?" Appealing to the Emperor's political aspirations, the Archbishop suggested that parish priests, with their extensive experience and trust of the populace, would prove more able and reliable administrators of the civil registers than the unpopular escrivães. Ultimately, wrote the Archbishop, the Emperor would, in his eminent wisdom, resolve as he saw fit, taking into account the temporal and spiritual well being of his subjects and "the protection of the Church as one of the most beautiful attributes of sovereignty."

Religious authorities were evidently less than pleased by the new law. Decree 798 did not suppress parish registers, but the creation of separate registers in the hands of escrivães must still have smacked as an affront to the Church. Once the uprisings began, however, religious authorities at all levels of the Church hierarchy consistently reiterated their support of the government. A circular sent from the Bishop of Pernambuco to parish priests in the province

\footnotetext{
36 This and all subsequent quotations from the Archbishop's letter come from its reproduction in O Argos Maranhense, n. 52, 20 Feb. 1852 (BNRJ-SOR, 897). The Archbishop's letter was originally published in Noticiador Catholico, n. 168, 15 Dec. 1851.
} 
on 3 January 1852, published on the front page of the Diario de Pernambuco on 8 January 1852, sent a clear message: "Aware that some inhabitants of several parishes have opposed the execution of the Imperial Decree n.798 . . which had no other aim than to provide the means necessary to effect the statistics of the whole empire, as is done in other countries, without any chance that it has, or could have, the sinister end that calumniously they have wanted to attribute to it: we determine that you, honorable reverends, employ all the means in your reach to make your parishioners see with the greatest clarity the manifest falsity of this unfounded slander, only intended to disrupt the peace and harmony on which the conservation of society especially depends."

Religious authorities' public cooperation with the government in confronting the uprising did not immunize them from the suspicion of some officials. There is no historical evidence that religious authorities incited their parishioners to take up arms against Decree 798, but the nature of the historical record makes it impossible to rule out this possibility. The surviving documents do suggest there was some reticence on the part of parish priests to the idea of civil registers: some priests decided to ignore the decree and others reported that they simply could not, in good conscience, carry it out. Overall, however, the correspondence between priests and their superiors suggests that local religious authorities did their best to negotiate the difficult position that Decree 798 put them in, balancing their desire to comply with the new law with their desire to maintain peace in their parishes and perform their pastoral duties. In their correspondence, vicars and parish priests described the difficulties of complying with the law in cases where individuals were unable to acquire the official certificate-whether due to a lack of official forms, residence great distances from the residence of an escrivão, or inability to pay the escrivão his nominal fee. Explaining his decision to continue providing the "regenerative sacrament" to newborns and ecclesiastic burial to the deceased, a vicar wrote to the provincial president that denying these services would drive the povo to complete despair. Another vicar wrote that he was not opposed to the law of the government, but had suspended the execution of the decree in his parish to avoid "much blood being spilled.",37

Whether the instigators of the revolt were depicted as seditious Liberals or conspiring priests, the official accounts were virtually unanimous in attributing the revolt to the duping of the "povo ignorante" through the intentional spread of "untenable" rumors. Referred to as "stupid" and "insensible," "ignorants" and "fanatics," the povo that rose up in opposition to civil registration was divested of any inkling of reasoned agency. From the perspective of the imperial political elite, the uprising was orchestrated by men who either vied with the party in power for political authority or felt threatened by the state's

37 APEP-DM-AE 1852: docs. 2-3. 
encroachment into the terrain of their symbolic authority. In either case, the official interpretation of the revolt was that opponents of the imperial government manipulated the easily misled populace by preying on their ignorance and kindling their "irrational" fears.

This was the prevailing consensus in official reports and pro-government newspapers of the time. This is also the interpretation put forth by historian Hamilton de Mattos Monteiro, in one of the few contemporary accounts of the incident: "At first glance, the sedition appeared to be a movement of the poorest rural population against the large landowners (Senhores de Engenho) and local authorities. But could these 'tenants' and 'proletariats,' so removed from elite culture, be able to judge for themselves the content of Decrees 797 and 798 and associate it with the repression of the slave trade. .? We do not believe so" (Monteiro 1980: 122). Citing the claims made by Conservative party leaders and pro-government newspapers as evidence, Monteiro argues that the civil registration decree was just a pretense for opponents of the government to stir up trouble. The revolt was produced through the concerted efforts of Liberals, religious authorities and radicals who wanted to destabilize the government. It was, in effect, a rather feeble effort to re-ignite the Praieira rebellion that had destabilized the province only a few years before.

As in the case of priests, it is certainly possible that political opponents of the Conservative party started the rumor that Decree 798 was a "law of captivity." They may have seized upon the opportunity created by the government's ill-timed civil registration initiative to undermine the "party of order" by inciting rebellion. The nature of the surviving evidence makes it impossible to rule out this possibility. However, that evidence does not positively support this interpretation either. It does not suffice to take Conservative charges against possible Liberal conspirators as objective evidence of a politically inspired conspiracy.

Much like the explanations expounded by the Conservative party sources which he cites, Monteiro's account of the revolt divests the rural population of any capacity for autonomous action. The povo is ignorant, un-politicized, and unaware, and thus could not possibly have risen up against the decree of its own accord. Moreover, even if it was the case that conspiring Liberals or parish priests started the rumor about the decree, Monteiro offers no explanation for why such a rumor would resonate with the northeastern rural poor and lead them to disrupt their lives and take up arms against local authorities. Monteiro's account points to suspected instigators of the rumor that Decree 798 was a "law of captivity," but it does not explain why the attempt to implement the decree spurred widespread participation in a violent popular revolt. To understand why Decree 798 provoked the war of the wasps demands consideration of how the decree, and the rumors surrounding its implementation, were perceived by the poor, rural population of Brazil's northeastern backlands. 
THE VIEW FROM BELOW: IN DEFENSE OF LIFE AND AFTERLIFE

It may actually be that a resentful Liberal or disgruntled priest started the rumor that civil registration would be used to enslave free people of color. Alternately, it could be that individuals amongst the free rural poor came to this conclusion themselves, then relied on traditional channels of oral communication to spread the "news" across the northeastern interior. As Steven Hahn has argued, rumor can be construed as a "form of popular political discourse" that is ideally suited to marginalized or repressed social groups: "Its source is cloaked in anonymity; it normally flows through established channels of everyday life; and it is open to continuous improvisation and embellishment, thereby activating and energizing (in effect politicizing) those who become involved in its circuits" (Hahn 2003, 57-58; see also Scott 1990, 144-48; Lefebvre 1973). In the absence of surviving evidence to incriminate either Liberals or parish priests, there is no reason to rule out the possibility that the rumor linking civil registration to enslavement of the free poor of color started "from below."

Whatever its source, the crucial question is why the rumor that Decree 798 was a "law of captivity" resonated with the population. It is clear that enslavement of the free poor of color was not among the government's aims in issuing Decree 798. As noted above, escrivães were not even instructed to record the "color" of free newborns, nor was color of free persons to be recorded in the 1852 census. That the rumor was untrue, however, makes little difference for understanding the driving force behind the popular uprising. What matters is that the rumor resonated with the population.

The rumor's role in inciting the rebellion is highlighted in the reports of local authorities to their superiors. In one instance, a priest reported that his parishioners said they "... .refused to obey this law, for being something never before seen [por ser couza nunca vista], and that with it the Government wanted to capture them; that they would prefer their children to die pagans, and bury their cadavers in the countryside, rather than give their names in the house of the escrivão." The priest reported that he had administered sacred rites without the required certificates because the escrivão had not received the official book from the Municipal Council. He explained that "upon seeing that I administered the baptism without the paper from the Escrivão of the Peace, [the rebels] withdrew, shooting off their guns, shouting "vivas" for having won, and yelling that they would rather die than register the baptism of their children with the Escrivão to end up captives.",38

In addition to the accounts of local authorities, some of the rebels in Pau d'Alho made a declaration to the interim police chief on 2 January 1852, which read in part: "We, poor blacks and mulattos, having heard news of the paper of slavery that today was supposed to be read, we wish to know from

${ }^{38}$ APEP-DM-AE: doc. 16. 
You Sir, as the superior authority in charge, if it is or is not the truth. ..."39 This declaration - an unusual piece of direct evidence of the concerns of the governed-confirms official accounts that the threat of captivity was a central motivation for the uprising.

Why did the rumor that Decree 798 was a "law of captivity" ring true for the northeastern rural populace? The Bishop of Pernambuco surmised that the idea that the government could entertain such "abominable, perverse intentions" was outside the realm of "common sense." 40 A spokesman of the Liberal party clamored that "the Permanbucan povo, even the least learned, has enough common sense" not to be deceived by those "who would have him believe in the tales of. . . a thousand and one nights." 41 But contrary to these sorts of claims - and despite them - the idea that the government would pass a decree designed to enslave the free poor of color proved perfectly conceivable to the northeastern rural poor.

In the most detailed published account of the war of the wasps to date, Guillermo Palacios argues that the revolt was an attempt by the free rural poor to defend their socioeconomic and symbolic status, as freepersons in a slave society, against changes wrought by the shifting political economy of the region. Brazil definitively banned the importation of African slaves in 1850 , responding to British political pressure and threats of naval intervention (Barman 1988: 233; Bethell 1970). The end of the international traffic promised to tighten the domestic slave market, forcing large agricultural producers to rely increasingly on free labor. The census and civil registration decrees, according to Palacios, were the "poor cousins" of a spree of laws that aimed to restrict the social and economic mobility of the free poor. Most notable among these were the Land Law (Lei de Terras 1850), which placed new restrictions on access to land, and a law making advancement to officer in the National Guard appointive rather than elective, which removed what may have been an important mechanism for limited mobility among the "honorable poor." 42 Alongside such measures, Palacios suggests, the idea that Decree 798 was a "law of captivity" seemed consistent with what could only have been conceived as a broader agenda by the powerful to secure a fixed labor supply by exerting total control over the lives of the free poor. As Palacios explains:

The protagonists [sublevados] of 'The War of the Wasps' rose up against a series of events which began to take place around 1850, and which represented to them ... clear signs that a great change was afoot, and that that change, whose significance they clearly and correctly perceived with startling foresight, would ultimately be

\footnotetext{
39 The declaration was published in Diario de Pernambuco, 16 Feb. 1852: 2.

40 Circular from Bishopric of Pernambuco published on front page of Diario de Pernambuco, 10 Jan. 1852: 2.

41 O Paladim, 5 Feb. 1852: 2 (BNRJ-SOR, P19, 4, 9).

42 More research is needed to clarify whether the National Guard actually provided much opportunity for social mobility. On this question, see Castro (1977); Kraay (2001: 249-50).
} 
concretized at their expense. They, the free, poor men and women of Northeastern Brazil, autonomous rural cultivators, were the first line of reserves for the plantations at the onset of the terminal crisis of slavery. The revolt against civil registration [o Registro] showed that they were plainly conscious of this (1989: 16).

Taking this argument a step further, Palacios suggests that the revolt against Decree 798 was also, in a sense, "a revolt against the extinction of slavery" (1989: 17). As miserably poor as they might be, as long as there were slaves, the free poor were "saved from complete subjection to labor on the plantations," and could at least be grateful for their legal freedom. The end of the slave trade threatened this source of status honor for the free poor. Opposition to the rumored "law of captivity" reinforced the distinction between slave and free. Therefore, on Palacios' account, the revolt was an indirect defense of the continued existence of slavery (1989: 17).

Palacios' account is complicated, however, by three considerations. First, although the international slave traffic was extinguished in 1850 , slavery continued to exist domestically until 1888 . From the perspective of the free rural poor, the extinction of slavery per se was still nowhere in sight in 1852 . Northeastern slave owners, for their part, remained confident about the future of slavery into the 1860 s, at least; their outlook shifted gradually over time (Slenes 1976: 203-4). If 1850 marked "the beginning of the terminal crisis of slavery," it seems that it did so for the inhabitants of the sugar-producing regions of the northeast only in retrospect, looking back from at least the 1870 s, and possibly even later.

Second, it is unlikely that the free rural poor in the northeastern sugar regions and adjacent areas felt direct material consequences of the ban on slave imports by 1852 . Contrary to the conventional story in Brazilian historiography, the northeastern sugar plantations did not lose large numbers of slaves through inter-regional trade to the increasingly profitable southeastern coffee regions from 1850-1870. As Robert Slenes concluded based on intensive scrutiny of available primary sources, "it would seem that slavery remained profitable as a labor system on the northeastern plantations throughout most of the post-1850 period." As a consequence, the inter- regional slave traffic remained quite small, did not really peak until the $1870 \mathrm{~s}$, and then consisted mostly of non-plantation slaves (Slenes 1976: 207-8; Klein 1971). In fact, Pernambucan sugar municipios were probably net importers of slaves into the 1870 s (Slenes 1976: 214). Thus, in the 1850 s the northeastern sugar plantations remained slave-based and profitable; only several years after the ban on slave imports, and with the onset of steadily declining profits, would the fazendeiros become fixated on further limiting the mobility of the free rural poor.

Finally, Palacios' argument also contains a problematic assumption. Even if the freedoms of the free poor were in fact increasingly restricted following the ban on slave imports, that they opposed restrictions on their own freedom is not sufficient evidence to argue that their protest signified support for the continued 
enslavement of others. Of course, the end of the international slave trade in 1850 may well have made the free poor uneasy about the future, and this uneasiness may have made them more receptive to rumors about a "law of captivity" in the early days of 1852 .

Palacios' account of the war of the wasps is a vast improvement on Monteiro's. Palacios explicitly recognizes the rural poor as "protagonists of their own history" (1989: 64), fully capable of assessing potential threats to their security and reacting accordingly. In the end, however, Palacios' protagonists are projected into a master narrative not of their own making. Existing land tenure relations, the ban on slave imports, and the gradually shifting political economy of the region certainly set the stage for the war of the wasps. But the threats identified by Palacios, in retrospect, to be looming large over the northeastern rural poor in the early 1850 s were not transparently linked to the introduction of obligatory civil registration in 1852 . From the perspective of the free rural poor, the dire threats posed by civil registration lay in the specific provisions-rumored or actual-of Decree 798. While Palacios (1989: 52-53) notes that the "concrete problems" created by the regulations became mixed up in the motivations for participation in the revolt, I see popular perceptions of the specific and immediate threats posed by the implementation of Decree 798 as absolutely central to understanding why the introduction of civil registration incited a violent popular rebellion. The free rural poor in the northeastern interior rose up against Decree 798 in defense of their immediate material livelihoods and their spiritual well being in the hereafter.

That the revoltosos saw in civil registration a threat to their material livelihoods is evident in the widespread resonance of the rumor that Decree 798 was a "law of captivity." The rumor resonated, in turn, because the rural poor knew from experience that they were vulnerable to capricious state action. The state had long been in the business of depriving the free poor of their freedom, through forced recruitment into the army. Brazilian law subjected all single men between the ages of eighteen to thirty-five to forced recruitment, with the exception of brothers of minor orphans, oldest sons of widowed mothers, and, importantly, men who worked in useful economic activities or enlisted in civilian militias. These exemptions were not automatic, however; men could hope to avoid forced recruitment "only as long as they actually practice their trades and demonstrate good behavior" (Brazil. Colleção das Leis... 10 July 1822, cited in Kraay 2001: 185). The law thus gave authorities considerable discretion in identifying potential conscripts, and as is often the case, administrative discretion slid easily into abuse of power.

By the mid-nineteenth century, forced recruitment had become a favored means of dealing with the problems of "vagabondage" and non-homicidal crime (Beattie 1994). Unscrupulous authorities also used conscription to settle political scores or personal vendettas. Testifying to the frequent abuse 
of impressment for political ends, in 1846 the imperial government passed a law "prohibiting impressments one month before and two months following an election to check electorally inspired dragooning" (Beattie 2001: 35). The capricious abuse of conscription by local "tyrants" was decried in a Liberal paper in January of 1852: "The Emperor does not know what is going on in the provinces! The cries of the oppressed have not yet reached his ears! He does not know that through an unjust and deliberately planned process a doting father is ripped away from his innocent children, a faithful spouse torn from the arms of his partner! He does not know that with the terrible weapon of recruitment the little tyrants exercise the cruelest and meanest vengeance - and that this is the punishment that is applied to those who do not vote with the government...."43 Another opposition newspaper announced matter-of-factly, "recruitment in the northeastern provinces is the favorite weapon of today's men to crush their political and personal adversaries." 44

Filled mostly with vagrants, petty criminals and unfortunate desprotegidos (unprotected ones), mid-nineteenth-century army barracks became quasi-penal institutions (Beattie 2001). Enlisted military service became associated with marginality and captivity (Meznar 1992). Though not technically reduced to slavery, "recruits" were effectively stripped of their freedom and bore a stigma reminiscent of that born by slaves. Indeed, the status distinction between slaves and foot soldiers, whether in the army or the civilian militia, was often blurry, a fact underlined by an 1851 measure legalizing use of "the whip" to discipline troops in the national guard. Liberal papers decried the measure as an attack on the status of free Brazilians, as in the following frontpage editorial: "Who could have thought that in this century and in this country there would be a government so iniquitous that it would reduce self-respecting national guards to the condition of slaves? Who could have supposed that among us there would be a government so insolent as to condemn Brazilian citizens to the whip? ... The whip for free men, for citizens of a country that claims to have a liberal constitution! ... And where is that liberty? And that constitution? The Brazilian citizen is a citizen, he is free, but he is to suffer like a slave. ...",45

In the years immediately preceding the attempt to implement civil registration, the threat of impressment in northeastern provinces intensified. In Pernambuco, in particular, the provincial government had stepped up recruitment in response to the praieira rebellion (Marson 1987; Carvalho 1998). Fresh memories of coercive recruitment would have made the rumors surrounding Decree 798 particularly resonant to the populace, and may help

43 O Argos Natalense: Periodico politico e social do Rio Grande do Norte, n. 20, 10 Jan. 1852: 1 (BNRJ-SOR, P22B, 04, 182).

44 O Paladim, n. 13, 20 Oct. 1852: 12 (BNRJ-SOR, P19, 4, 9).

45 O Argos Natalense, 8 Nov. 1851 (BNRJ-SOR, P22B, 04, 182). 
to explain why Pernambuco was the epicenter of the war of the wasps. Elsewhere in the region, anxieties about forced recruitment were likely heightened by news of the impending military campaign against Argentina's Juan Manuel de Rosas. As it happened, Pedro II relied heavily on foreign mercenaries for that campaign, and the quick fall of Rosas in 1852 saved the imperial government from having to mobilize large numbers of Brazilians (Beattie 2001: 37). But when Decree 798 went into effect, this was not a foregone conclusion; the looming war with Argentina likely raised suspicions amongst the free poor that civil registers would be used to facilitate large-scale recruitment. While there is no evidence that civil registration or the census were actually linked to plans to intensify military conscription at this time, given the common practice of forced conscription, prospective "recruits" and their families may have viewed any measure that would facilitate their identification by agents of the state with trepidation. ${ }^{46}$

In this context, the rumor that Decree 798 was a "law of captivity" must have enjoyed an added ring of truth because illegal enslavement of free persons by corrupt provincial officials did occasionally occur. Historian Judy Bieber Freitas (1994) documents numerous cases of municipal officials colluding with local landed elites to illicitly enslave and trade free people of color in the interior of Minas Gerais from 1850-1871. Carvalho (1998) and Mosher (2005) note similar incidents in Pernambuco. No matter that it was illegal and, most likely, relatively uncommon; that the enslavement of free poor of color by agents of the state was known to happen at all would certainly have contributed to making the rumors surrounding Decree 798 believable. The argument made by supporters of the decree, that civil registration could only help support the freedom of the free by giving them proof of their free status, did little to ameliorate the situation. ${ }^{47}$ Moreover, such arguments could not have fallen lightly on the ears of those with ambiguous status, especially runaway slaves who eluded their owners by fleeing to the interior.

In sum, the prior experience of the northeastern rural poor in dealings with secular authorities gave them good reason to suspect the aims of civil registration. The idea that Decree 798 was a "law of captivity" was made plausible by their first-hand knowledge of abuses by agents of the state. But if it were true, such a law went far beyond the transgressions of individual state authorities (routine as they might be), by making enslavement of free men a legal practice, sanctified by the Emperor himself. This egregious violation of the traditional relationship between the free poor and the imperial state was

\footnotetext{
46 Civil registration would eventually become tied to conscription for military service, though not effectively so for at least another fifty years (Beattie 2001: 234-35, 270).

47 These claims were not necessarily disingenuous. When an obligatory national slave registration system was implemented following the passage of a "free womb" law in 1871, it created new burdens of proof for those who claimed another individual as their slave, making illicit transactions more difficult (see Bieber Freitas 1994: 597; Chalhoub 1990).
} 
reason enough to revolt. But the insult of Decree 798 went even further: on top of the attack to their livelihood and social status in the material world, Decree 798 threatened their prospects for redemption in the hereafter.

The free rural poor of Brazil's northeastern interior revolted against civil registration to defend their bodies from forced enslavement; but they also revolted to protect their souls from eternal damnation. In their declaration to local authorities of Pau d'Alho, protagonists of the revolt not only demanded to know if the lei do captiveiro was true, they also decried the news that "escrivães of the justices of peace, from today forward, are the ones in charge of baptisms, without a certificate from them a child cannot be made a Christian." ${ }^{48}$ In making civil certificates prerequisites for the receipt of religious rites, the government obviously intended to take advantage of the religiosity of the povo to ensure compliance with the new law. But the strategy backfired. The rural population rose up in defiance of what seemed a direct and arbitrary attack by secular authorities on their prospects for entering Heaven.

Brazil's northeastern rural population was (and is) deeply religious, heavily influenced by messianic renditions of Catholic cosmology. ${ }^{49}$ For many, access to "God's Kingdom" was the only real hope of eventually escaping the miserable, impoverished conditions of the drought-ridden backlands. They would not stand idly by while the government constructed capricious obstacles to their salvation. Armed with knives, machetes, and pistols, the inhabitants of one area (subdelegacia), for example, entered the "Temple of Peaceful God" on 1 January 1852 (the day Decree 798 was to go into effect) and threatened to assassinate anyone "who read any paper, or made any exhortation with respect to denying the administration of baptism without a certificate from an escrivão of the peace." 50 The arbitrary and seemingly senseless machinations of the state could be ignored or even tolerated up to a point. But in granting local secular officials the power to regulate access to Heaven - in making eternal salvation dependent on a piece of paper from an escrivão - the imperial government had gone too far. The parish priest who predicted that obstructing access to baptism of newborns would "do no more, nor less, than drive the povo to complete despair" was absolutely right. ${ }^{51}$

48 Document of the revoltosos to the Delegado Suplente of Pau d'Alho, dated 2 Jan. 1852, published in Diario de Pernambuco, 16 Feb. 1852: 2.

49 See, for example, Reis 2003; da Cunha 1944[1902].

50 APEP-DM-AE: doc. 16.

51 APEP-DM-AE 1852: doc. 2. Palacios (1989: 58) notes that the fact that the civil registers were placed in the hands of local secular authorities surfaced "now and then" as an apparent motive for the revolt. He writes that the civil registry and census decrees "had the property of invading the domestic intimacy of the rural family in many forms, opening the protective nucleus of the family unit to ever more constant and institutionalized [state] intervention" (p. 59). In contrast to the current account, however, Palacios does not conclude that this specific provision of the Decree was a primary impetus to the insurrection. 
The obstacle posed to baptism and religious burial by the required certification from an escrivão was far from trivial. Reaching an escrivão in the time allotted by Decree 798 would be quite a feat for those who lived at great distances from population centers. And even those within range of an escrivão might not have the cash they demanded, even if the fee were only equivalent to a day's work (as a conservative estimate). ${ }^{52}$ Adding to the injury, the "service" performed by the escrivães seemed ludicrous at best, menacing at worst. Mandating that a woman should walk for days across the arid backlands after giving birth just to tell a civil functionary her child's name was ridiculous enough; charging her a fee for the privilege and making the "regenerative sacrament" dependent on it was obscene. When combined with the rumor that registries would be used to enslave the free poor of color, the result was a slew of violent popular uprisings in settlements and small towns throughout the northeastern interior- the war of the wasps.

\section{BLINDED LIKE A STATE}

Truthfully, it would be necessary to lack the slightest knowledge of our interior, and be completely ignorant of the condition of our population, disseminated across the vast countryside and forests, to not see at a glance the stupidity that presided over the design of this decree... ${ }^{53}$

What provoked the revolt against civil registration in mid-nineteenth century Brazil? From the vantage point of the imperial political elite, popular opposition to such a transparently progressive measure could only have been instigated by conspiring Liberals or disgruntled parish priests. The povo, in its ignorance, could have neither reason nor incentive to take up arms against such a clearly necessary and beneficial measure. From the perspective of those who revolted, in contrast, civil registration loomed as a double threat: it not only jeopardized their already marginal social and economic status in this world, it also threatened to obstruct their inclusion in "God's Kingdom" in the next. Violent opposition seemed warranted and necessary to protect themselves from the threat of captivity, on the one hand, and the threat of spiritual damnation, on the other.

Ultimately, it would seem, the war of the wasps erupted from the deep gulf that separated the world of the imperial political elite from the world of

\footnotetext{
52 The fees themselves were rarely mentioned in reports of rebels' grievances by authorities in the northeast. In the province of Rio de Janeiro, meanwhile, complaints were lodged against escrivães for imposing fees arbitrarily: "The escrivães of the justices of the peace ... have not agreed on the fees they should charge those declaring deaths as required by the new law. Some are happy with 240rs, others demand 600rs. This irregularity must stop. ..." (Jornal do Commercio, 3 Jan. 1852: 2). In fact, these escrivães were illegally charging for taking declarations, when Decree 798 only permitted them to charge for issuing certificates. The fees mentioned here would probably have been equivalent to about a day or two of wages for an unskilled rural laborer in Pernambuco (see Eisenberg 1974: 190).

${ }^{53}$ From the liberal paper O Paladim, 5 Feb. 1852: 2 (BNRJ-SOR, P19, 4, 9).
} 
the impoverished rural population - the same gulf that made possible the coexistence of such starkly different understandings of a decree calling for civil registration of birth and death. As Roderick Barman has described, Brazil in the early 1850 s was characterized by a "fundamental duality in life and outlook" between the "official nation," composed predominantly of graduates from the few existing faculties of law and medicine, and the "real Brazil," composed of approximately eight million people, the vast majority of whom were rural, poor, and illiterate, and a quarter of whom were slaves (Barman 1988: 235-37; also Carvalho 1982). The unfolding of the war of the wasps epitomized the duality between the "official" and the "real" Brazil.

Needless to say, however, there were also tensions and conflicts within each of these worlds, which no doubt influenced how the revolt played out. That slaves did not appear to participate in the uprisings, for example, may help to account for the government's somewhat tempered response. The clamoring in local Liberal newspapers, meanwhile, reveals that not all political elites were equally blind to the hardships that Decree 798 imposed on the northeastern rural poor. Indeed, even in Pedro II's advisory body, the Council of State, one member dissented from the majority and flatly opposed the civil registration decree as it was conceived. Commenting on a handful of minor revisions to the decree made by the Council on 22 January 1852 in response to written complaints, the Visconde de Olinda argued that the decree should be revoked because it was fundamentally flawed. He favored a new civil registration law that would put the registers in the hands of vicars, and reasoned, "In subjects of this nature it is wise to respect popular prejudices, and always imprudent to confront them unnecessarily." win the day, but in the end neither did the plans of the majority. The revisions to Decree 798 never had the chance to be put into effect because civil registration was suspended indefinitely only a few days later, along with preparations already under way for the census.

Just as the worlds inhabited by "the elites" and the "marginal classes" were internally contentious, so the gulf that separated Brazil's officialdom from the majority of the population was never absolute. The "two Brazils" were connected through a variety of cultural and political intermediaries, among them parish priests, low-level civil functionaries, and traditional authority figures of various stripes. The juxtaposition of the "official nation" and the "real Brazil" thus implies a much neater and more dichotomous state of affairs than ever existed in practice. In a sense, the notion that there was a "fundamental duality" between the "official nation" and the rest of Brazil reflects political elites' own views of themselves in relation to the Brazilian population at large. Under the banner of modernization, and with utter faith in rationality and

54 AN-CX515 Pac. 2, doc. 38. 
progress, Brazil's nineteenth-century state-builders saw themselves as apart from, and above, the society they sought to govern. Against superstition, they would introduce rationality; against chaos, they would impose order; against backwardness, they would bring progress; and against tradition, they would usher in modernity. Political elites had nothing to learn from traditional authorities, no reason to concern themselves with local knowledge.

Among the imperial political elite, knowledge of the "real" Brazil was both limited and devalued. Prevailing lifestyles and worldviews in "the interior" of the country - conceived as virtually the entire expanse of Brazilian territory beyond the Court in Rio - were seen as obstacles to be overcome or barbarisms to be vanquished. As a consequence, the imperial political elite failed to recognize the potential value of local structures of authority and knowledge for the pursuit of their own ends. In the case of the war of the wasps, in particular, potential bridges between the official world and that of the northeastern rural poor were not recognized as such. Parish priests, for example, could well have facilitated the introduction of civil registers in the 1850s. But they were dismissed as unsuitable allies in the quest to modernize Brazil. ${ }^{55}$ In circumventing priests and placing the registers in the hands of the escrivães, the state fueled the fires of suspicion amongst an already distrustful populace. Add to this the confluence of the general feelings of the rural poor of vulnerability to a capricious state, the rumored threat of captivity, and the decree's onerous and "anti-Christian" provisions, and a measure that might otherwise have been ignored - as analogous measures were in other contexts - instead ignited a consequential revolt.

In the quotation cited in the introduction to this article, Scott notes that pre-modern states' attempts to intervene in society were often "crude and selfdefeating." At least in part, this was because pre-modern states lacked adequate "maps" of their human and natural resources. The development of standardized schemes to impose order on messy realities - censuses, standardized weights and measures, cadastral maps, and the like-helped to deliver pre-modern states from their blindness. With the development of "tools of legibility," Scott suggests, the "vision" of the state-and its capacity to intervene in society-improved dramatically.

But did it? Legibility projects certainly altered states' vision. There is no question that censuses, for example, brought things into states' view that were previously invisible or obscure. In addition to illuminating existing realities, censuses also changed what states saw by reconstituting, in their own terms, the reality they purported to describe. Legibility projects changed

\footnotetext{
55 This point is elaborated in Loveman 2005: 1672-74. On church-state relations in Brazil, see Meecham (1947) and Boxer (1978).

56 The quotation is from an editorial critical of Decree 798 in O Echo Liberal (Piaui), 8 Jan. 1852 (BNRJ-SOR PR910-930).
} 
what states could see in part through changing the nature of what it is they did see. While these alterations in how and what the state could see were often dramatic, however, it is not clear that taken as a whole the state's vision improved with the use of these technologies.

At the very least, it seems that improvements in the "synoptic" vision of the state went hand in hand with a deterioration of states' propensity to see and understand the particularities and nuances of local realities. Indeed, this is affirmed by Scott's (1998) own account of how several grand "schemes to improve the human condition" through central state planning culminated instead in large-scale disasters. The twentieth-century calamities he describes testify to "high modernist" state elites' blindness to entire domains of knowledge and practice. And as Scott argues in his conclusion to Seeing Like a State, the failure of technocratic and political elites to take local, practical knowledge, or métis, into account was central to these tragic failures.

The blindness of twentieth-century high modern state technocrats to local knowledge - foreshadowed by their nineteenth-century predecessors' disregard for local modes of life - continues to echo in many state-led development projects today. This suggests that if the technical vision of modernizing states improved with the adoption of various "tools of legibility," the blindness brought on by modernist convictions - the inability to see in "traditional" relationships or ways of life potential allies or resources in the pursuit of progress - was not cured by taking a census or standardizing weights and measures. If anything, as Scott's (1998) analysis confirms, with respect to the modernizing state's blindness to contextualized needs and concerns, legibility projects were apt to make things worse.

For nineteenth-century state builders, meanwhile, the inability (or unwillingness) to "see" local realities proved a serious obstacle to the development of the state's administrative capacity and legitimacy. Modernization projects that appeared perfectly reasonable on paper regularly hit up against the realities of local conditions and popular understandings of how things ought to be. Such clashes could be costly, both for the targets of modernization projects and for their perpetrators. Undoubtedly, socially marginal populations disproportionately bore the costs of the state's blindness to local context. This was certainly the general pattern in the history of Brazil; the Canudos massacre of 1896-1897 stands out as a particularly ignominious example. ${ }^{57}$ But the blindness of state-modernizers to local realities also imposed serious costs on state-building projects themselves.

In the case of Brazil, in particular, state-builders' modernist ideological commitments, which defined away customary beliefs and practices as modernity's antithesis, no doubt contributed to many detours and delays in the effort to

\footnotetext{
57 On the Canudos episode in 1896-1897, which culminated in the deaths of an estimated 25,000 "backlanders" at the hands of the state, see da Cunha (1944)[1902], and Levine (1992).
} 
construct a modern state. The case of the war of the wasps is of course particularly ironic in its illustration of this general point, since the administrative innovation undermined by modernizers' blindness to local conditions aimed precisely at making the population more "visible" to agents of the state. The revolt against civil registration in nineteenth-century Brazil may be exceptional in its irony, but not in its more general lesson: to maximize their effectiveness and to minimize their collateral damage, modernizers are apt to fare better when they evince sensitivity to the local conditions they intend to transform, even if for no other reason than to avoid stirring up the grumbling hive. ${ }^{58}$

\section{REFERENCES}

Barickman, B. J. 1996. "Persistence and Decline: Slave Labour and Sugar Production in the Bahian Recôncavo, 1850-1888." Journal of Latin American Studies 28: $581-633$.

1999. "As Cores do Escravismo: Escravistas 'Pretos', 'Pardos' e 'Cabras' no Recôncavo Baiano, 1835.” População e Família 2, 2: 7-62.

. 2003. "Reading the 1835 Censuses from Bahia: Citizenship, Kinship, Slavery, and Household in Early Nineteenth-Century Brazil." The Americas 59, 3: 287-323.

Barman, Roderick J. 1977. "The Brazilian Peasantry Reexamined: The Implications of the Quebra-Quilo Revolt, 1874-1875." Hispanic American Historical Review 57, 3: 401-24.

sity Press.

Beattie, Peter M. 1994. Transforming Enlisted Army Service in Brazil 1864-1940: Penal Servitude versus Conscription and Changing Conceptions of Honor, Race, and Nation. Ph.D. dissertation, University of Miami.

. 2001. The Tribute of Blood. Army, Honor, Race and Nation in Brazil, 18641945. Durham, N.C.: Duke University Press.

Bento, Cláudio Moreira. 1986. "A revolução farroupilha vista por ocasião do seu sesquicentenário." Revista do Instituto Histórico e Geográfico Brasileiro, 147, 350 (Jan.-Mar.): 69-98.

Bethell, Leslie. 1970. The Abolition of the Brazilian Slave Trade: Britain, Brazil and the Slave Trade Question, 1807-1869. Cambridge, U.K.: Cambridge University Press.

Bianco, Lucien. 2001. Peasants without the Party: Grass-Roots Movements in Twentieth-Century China. Armonk, N.Y.: M. E. Sharpe.

Bieber Freitas, Judy. 1994. "Slavery and Social Life: Attempts to Reduce Free People to Slavery in the Sertão Mineiro, Brazil, 1850-1871." Journal of Latin American Studies 26: 597-619.

Bieber, Judy. 2001. “A 'Visão do Sertão': Party Identity and Political Honor in Late Imperial Minas Gerais, Brazil.” Hispanic American Historical Review 81, 2: 309-42.

Blackburn, Susan. 2004. Women and the State in Modern Indonesia. Cambridge: Cambridge University Press.

Boxer, C. R. 1978. The Church Militant and Iberian Expansion, 1440-1770. Baltimore: Johns Hopkins University Press.

58 The phrase "grumbling hive" is borrowed from Davison's title (1992). 
Boylan, Kristina A. 2002. "The Feminine 'Apostolate in Society' versus the Secular State: The Unión Femenina Católica Mexicana, 1929-1940.” In, Paola Bacchetta and Margaret Power eds., Right Wing Women: From Conservatives to Extremists around the World. New York: Routledge, 169-82.

Brazil. 1849. Relatorio que à Assemblea Legislativa Pernambucana apresentou na sessão ordinaria de 1849 O Exmo. Senhor Manoel Vieira Tosta, presidente da misma provincia. Pernambuco: Typographia de M.F. de Faria.

—. 1852a. Ministério da Justiça. Relatorio apresentado à Assembléa Geral Legislativa na Quarta Sessão da Oitava Legislatura pelo Ministro e Secretario d'Estado dos Negocios da Justiça Euzebio de Queiroz Coitinho Mattoso Camara. Rio de Janeiro: Typographia Nacional. (Available on-line at: http://wwwcrl-jukebox. uchicago.edu/bsd/bsd/u1843/index.html)

- 1852b. Collecção das leis do império do Brasil de 1851. Rio de Janeiro: Typographia Nacional.

—.1852c. Relatorio que à Assembléa Legislativa Provincial de Pernaambuco [sic] apresentou na sessão ordinaria do 1. de março de 1852 o excellentissimo presidente da mesma provincia, o dr. Victor de Oliveira. Pernambuco: Typ. de M. F. de Faria.

—. 1853. Relatorio apresentado á Assembléa Geral Legislativa na primeira sessão da nona legislatura pelo Ministro e Secretario d'Estado dos Negocios do Imperio, Francisco Goncalves Martins. Rio de Janeiro: Typographia Nacional. (Available on-line at: http://wwwcrl-jukebox.uchicago.edu/bsd/bsd/u1724/000033.html)

Brazil. Congresso. Câmara dos Deputados. 1977. Perfis Parlamentares 1: José de Alencar. Discursos Parlamentares. Brasília: Câmara dos Deputados.

Brazil. Directoria Geral de Estatistica. 1875. Relatorio e Trabalhos Estatísticos Apresentado Ao Illm e Exm. Sr. Conselheiro Dr. João Alfredo Corrêa de Oliveira, Ministro e Secretário do Estado dos Negocios do Império Pelo Director Geral Interino Dr. José Maria do Coutto. Rio de Janeiro: Typographia de Pinto Brandão e Comp.

Brazil. Senado Federal. 1978. Anais do Senado do Imperio do Brasil. Brasilia: Subsecretaria de Anais.

Burg, David F. 2003. A World History of Tax Rebellions: An Encyclopedia of Tax Rebels, Revolts and Riots from Antiquity to the Present. New York: Routledge.

Carvalho, José Murilo de. 1982. "Political Elites and State Building: The Case of Nineteenth-Century Brazil." Comparative Studies in Society and History 24, 3: $378-99$.

. 1996. "Cidadania: tipos e percursos." Estudos Históricos (Rio de Janeiro) 18: $1-21$.

Carvalho, Marcus Joaquim Maciel de. 1998. Liberdade: Rotinas e rupturas do escravismo no Recife, 1822-1855. Recife: Editora Universidade de UFPE.

2003. "Os nomes da revolução: lideranças populares na insurreição praieira, Recife, 1848-1849.” Revista Brasileira de História 23, 45: 209-38.

Castro, Jeanne B. d. 1977. A Milícia Cidadã: a Guarda Nacional de 1831-1850. São Paulo: Companhia Editora Nacional.

Chace, Russell E. 1989. 'Protest in Post-emancipation Dominica: The 'Guerre Negre' of 1844." Journal of Caribbean History 23, 2: 118-41.

Chalhoub, Sidney. 1990. Visões da Liberdade: Uma história das últimas décadas da escravidão na corte. São Paulo: Companhia das Letras.

Cleary, David. 1998. "'Lost Altogether to the Civilised World': Race and the Cabanagem in Northern Brazil, 1750-1850." Comparative Studies in Society and History 40, 1: $109-35$.

Cohen, I. Bernard. 2005. Triumph of Numbers: How Counting Shaped Modern Life. New York: W. W. Norton \& Co., Inc. 
Conselho Nacional de Estatística. 1951. "Legislação Básica do Recenseamento de 1940. Anexo XXVI. Reforma do Registo Civil de Nascimentos, Casamentos e Óbitos (projeto)". Documentos Censitários. Série A, Número 3. IBGE: Rio de Janeiro.

Cronin, Stephanie. 2003. "Modernity, Change and Dictatorship in Iran: The New Order and Its Opponents, 1927-29." Middle Eastern Studies 39, 2: 1-36.

Cunha, Euclides da. 1944[1902]. Rebellion in the Backlands. Samuel Putnam, trans. Chicago: University of Chicago Press.

Davison, Lee, ed. 1992. Stilling the Grumbling Hive: The Response to Social and Economic Problems in England, 1689-1750. Stroud, Gloucester: Alan Sutton; New York: St. Martin's Press.

Diamant, Neil J. 2001. "Making Love 'Legible' in China: Politics and Society during the Enforcement of Civil Marriage Registration, 1950-66." Politics \& Society 29, 3: 447-80.

Eisenberg, Peter L. 1974. The Sugar Industry in Pernambuco: Modernization without Change, 1840-1910. Berkeley: University of California Press.

Flores, Moacyr. 1978. Modelo Politico dos Farropos: As Idéias Políticas da Revolução Farroupilha. Porto Alegre: Editora Mercado Aberto.

Forrest, Alan. 1989. Conscripts and Deserters: The Army and French Society during the Revolution and Empire. Oxford: Oxford University Press.

Goldthorpe, J. E. 1952. "Attitudes to the Census and Vital Registration in East Africa." Population Studies 6, 2: 163-71.

Graham, Richard. 1990. Patronage and Politics in Nineteenth-Century Brazil. Stanford: Stanford University Press.

Hahn, Steven. 2003. A Nation under Our Feet: Black Political Struggles in the Rural South from Slavery to the Great Migration. Cambridge, Mass. and London: The Belknap Press of Harvard University Press.

Janotti, Maria de Lourdes Mônaco, 1987. A Balaiada. São Paulo: Brasiliense.

Joffily, Geraldo Irenêo. 1976. O quebra-quilo: A revolta dos matutos contra os doutores (1874). Revista de História, 54: 69-145.

Klein, Herbert. 1971. "The Internal Slave Trade in Nineteenth-Century Brazil: A Study of Slave Importations into Rio de Janeiro in 1852." Hispanic American Historical Review, 51, 4: 567-85.

Kraay, Hendrik. 1992. “'As Terrifying as Unexpected': The Bahian Sabinada, 18371838." Hispanic American Historical Review 72, 4: 501-27.

2001. Race, State and Armed Forces in Independence Era Brazil. Stanford: Stanford University Press.

Lefebvre, Georges. 1973. The Great Fear of 1789: Rural Panic in Revolutionary France. New York: Vintage Books.

Levi, Margaret. 1997. Consent, Dissent, and Patriotism. Cambridge: Cambridge University Press.

Levine, Robert M. 1992. Vale of Tears: Revisiting the Canudos Massacre in Northeastern Brazil, 1893-1897. Berkeley: University of California Press.

Lewin, Linda. 2003. Surprise Heirs (Vol. 2): Illegitimacy, Inheritance Rights, and Public Power in the Formation of Imperial Brazil, 1822-1889. Stanford: Stanford University Press.

Loveman, Mara. 2001. Nation-state Building, Race and the Production of Official Statistics: Brazil in Comparative Perspective. Ph.D. dissertation, University of California, Los Angeles.

. 2005. "The Modern State and the Primitive Accumulation of Symbolic Power." American Journal of Sociology 110, 6: 1651-83. 
Marinov, Dimitur. 1892. Zhiva starina: etnografichesko (folklorno) spisanie. Vol III: Semeiniia zhivot na naroda. Russe: Pechatnitsa sv. Kiril i Metodii.

Marson, Izabel Andrade. 1980. Movimento Praieiro: Imprensa, Ideología y Poder Político. São Paulo: Editora Moderna.

- 1987. O imperio do progresso: a revolução praieira em Pernambuco. São Paulo: Editora Brasiliense.

McCreery, David. 2002. "State and Society in Nineteenth-Century Goias". In, James Dunkerley ed., Studies in the Formation of the Nation State in Latin America. London: Institute of Latin American Studies, 133-60.

Meecham, J. Lyod. 1947. Church and State in Latin America. Chapel Hill: University of North Carolina Press.

Meira, Sílvio. 1994. "Dados históricos sobre o registro civil no Brasil." Revista do Instituto Historico e Geográfico Brasileiro 155, 382: 48-53.

Melo, Mario. 1918. Pau d'Alho: Geographia physica e politica. Recife: Officinas graphicas da Imprensa Official.

- 1920. "Guerra Dos Maribondos." Revista do Instituto Arqueológico, Histórico e Geográfico Pernambucano 22: 38-47.

Meyer, John. 1987. "The World Polity and the Authority of the Nation-State". In, George Thomas, John Meyer, Francisco Ramirez, and John Boli, Institutional Structure: Constituting State, Society, and the Individual. Newbury Park: SAGE Publications.

Meznar, Joan E. 1992. "The Ranks of the Poor: Military Service and Social Differentiation in Northeast Brazil, 1830-1875." Hispanic American Historical Review 72, 3: $335-51$.

Monteiro, Hamilton de Mattos. 1980. Crise Agraria e Luta de Classes: O Nordeste brasileiro entre 1850 e 1889. Brasilia: Horizonte Editora Limitada.

-1981. Nordeste Insurgente. São Paulo: Editora Brasiliense.

Mosher, Jeffrey. 2005. "The Struggle for the State: Partisan Conflict and the Origins of the Praieira Revolt in Imperial Brazil." Luso-Brazilian Review 42, 2: 40-65.

Needell, Jeffrey D. 2001. "Party Formation and State-Making: The Conservative Party and the Reconstruction of the Brazilian State." Hispanic American Historical Review 81, 2: 259-308.

Noiriel, Gérard. 2001. "The Identification of the Citizen: The Birth of Republican Civil Status in France". In, Caplan, Jane and John Torpey, eds., Documenting Individual Identity. Princeton: Princeton University Press.

Palacios, Guillermo. 1989. “A 'Guerra dos Maribondos': Uma Revolta Camponesa no Brasil Escravista (Pernambuco, 1851-1852)—Primeira Leitura.” História: Questões e Debates (Curitiba) 10, 18-19: 7-75.

Pearce, Adrian J. 2001. "The Peruvian Population Census of 1725-1740." Latin American Research Review 36, 3: 69-104.

Ploux, François. 1999. "Politique, rumeurs et solidarites territoriales dans les resistances au recensement de 1841." Cahiers D'Histoire 44, 2: 237-66.

Posel, Deborah. 1995. "State, Power, and Gender: Conflict over the Registration of African Customary Marriage in South Africa c. 1910-1970." Journal of Historical Sociology 8, 3: 223-56.

Redding, Sean. 2000. "A Blood-Stained Tax: Poll Tax and the Bambatha Rebellion in South Africa." African Studies Review 43, 2: 29-54.

Reis, João José. 1993. Slave Rebellion in Brazil: The Muslim Uprising of 1835 in Bahia. Arthur Brakel, trans. Maryland: Johns Hopkins University Press.

- 2003. Death Is a Festival: Funeral Rites and Rebellion in Nineteenth-Century Brazil. H. Sabrina Gledhill, trans. Chapel Hill: University of North Carolina Press. 
Santos, Fernando Pio de. 1994. Apontamentos Biográficos do Clero Pernambucano: 1535-1935. II. Recife: Arquivo Público Estadual Jordão Emerenciano.

Scott, James C. 1990. Domination and the Arts of Resistance. New Haven: Yale University Press.

1998. Seeing Like a State: How Certain Schemes to Improve the Human Condition Have Failed. New Haven: Yale University Press.

Secreto, María Verónica. 2003. "Sem medida: revoltas no nordeste contra as mediçoes imperiais." Paper presented at V Congresso Brasileiro de História Econômica e 6 a Conferencia Internacional de História de Empresas ABPHE. Caxambu, Minas Gerais, 7-10 Sept.

Singha, Radhika. 2003. "Colonial Law and Infrastructural Power: Reconstructing Community, Locating the Female Subject." Studies in History 19, 1: 87-126.

Slenes, Robert W. 1976. The Demography and Economics of Brazilian Slavery: 18501888. Ph.D. dissertation, Stanford University.

Souza e Silva, Joaquim Norberto de. 1986[1922]. Investigações sobre os recenseamentos da população geral do império. Resumo histórico dos inquéritos censitários realizados no Brasil. IPE-USP: São Paulo.

Tilly, Charles. 1990. Coercion, Capital, and European States, A.D. 990-1992. Cambridge: B. Blackwell.

Toplin, Robert B. 1972. The Abolition of Slavery in Brazil. New York: Atheneum.

Ventresca, Marc J. 1995. When States Count: Institutional and Political Dynamics In Modern Census Establishment, 1800-1993. Ph.D. dissertation, Stanford University. Yin, Jun-lin. 1999. "Agitation against Investigating the Number of Permanent Residence [sic] in the 1rd [sic] Year of Emperor Xuan Tong." Lishi Dang'an 3: 110-13. 